Migration Studies - Review of Polish Diaspora nr 2 (172)/2019, http://www.ejournals.eu/Studia-Migracyjne/

10.4467/25444972SMPP.19.019.10845

\title{
Imigranci na regionalnym rynku pracy: doświadczenia cudzoziemców i skala zjawiska w województwie zachodniopomorskim
}

\author{
ANITA ADAMCZYK ${ }^{1}$ \\ Uniwersytet im. Adama Mickiewicza w Poznaniu \\ ROBERT BARTŁOMIEJSKI \\ Uniwersytet Szczeciński \\ DOROTA KOWALEWSKA \\ Uniwersytet Szczeciński
}

Celem niniejszego artykułu jest analiza sytuacji imigrantów zarobkowych na zachodniopomorskim rynku pracy. Dane dotyczące imigracji zarobkowej do województwa zachodniopomorskiego zostały odniesione do uwarunkowań regionalnego rynku pracy. Autorzy w artykule odwołują się ponadto do danych pochodzących z wywiadów z imigrantami i ekspertami. Na ich podstawie dokonano analizy sytuacji rodzinnej, ekonomicznej i społecznej imigracji zarobkowych. Zgromadzone dane wskazują, że zdecydowaną większość imigrantów zarobkowych w województwie zachodniopomorskim stanowili Ukraińcy. Ich przyjazd do Szczecina i regionu zachodniopomorskiego, podyktowany był, w pierwszej kolejności relatywnie wysokimi zarobkami, a następnie bliskością językową i kulturową. Z przeprowadzonych badań wynika, że w tej chwili mamy do czynienia w województwie zachodniopomorskim ze zjawiskami typowymi dla imigracji „pierwszej fali”. Dla tego etapu pracy zarobkowej cudzoziemców charakterystyczna jest częstsza zmiana miejsca zatrudnienia, wydłużanie godzinowego czasu pracy i mniejsza liczba kontaktów pomiędzy imigrantami.

Słowa kluczowe: województwo zachodniopomorskie, imigranci ekonomiczni, trendy migracyjne, zatrudnienie cudzoziemców

'Kontakt: anita.adamczyk@amu.edu.pl, robert.bartlomiejski@usz.edu.pl, dorota.kowalewska@usz.edu.pl

Sugerowany styl cytowania: Adamczyk A., Bartłomiejski R., Kowalewska D. (2019), Imigranci na regionalnym rynku pracy: doświadczenia cudzoziemców i skala zjawiska w województwie zachodniopomorskim, "Studia Migracyjne - Przegląd Polonijny”, 2 (172): 161-184. DOI: 10.4467/25444972SMPP.19.019.10845 


\section{Immigrants on the regional labor market: experiences of foreigners and the scale of the phenomenon in the West Pomeranian Voivodeship}

The aim of the article is to analyze the situation of economic immigrants on the West Pomeranian labor market. The data on immigration to Zachodniopomorskie Voivodship is related to the characteristics of the regional labor market. The authors refer to data from interviews with migrants and experts. On this basis, the analysis of the families and economic and social situation of economic immigration was made. The collected data indicate that the vast majority of economic migrants in the West Pomeranian Voivodship were Ukrainians. Their arrival in the West Pomeranian region was related with relatively high wages, and with the linguistic and cultural proximity of Poland (pull factors). The research shows that at the moment we are dealing with phenomena which are typical of first wave immigration in the West Pomeranian Voivodship. This stage is characterized by a more frequent change of place of employment, longer working hours and, among other, a smaller number of contacts between immigrants.

Keywords: West Pomeranian voivodship, economic immigrants, migration trends, employment of foreigners

\section{Wprowadzenie}

Województwo zachodniopomorskie jest piątym co do wielkości województwem, zajmującym ponad 7\% powierzchni i skupiającym niemal 4,4\% populacji kraju. Obszar ten, podobnie jak inne województwa, coraz częściej doświadcza napływu cudzoziemców. Dokładne ustalenie ich liczby jest jednak bardzo trudne. Źródła statystyczne nie są bowiem spójne, mają charakter fragmentaryczny i są rozproszone. W rocznikach statystycznych Głównego Urzędu Statystycznego dotyczących województw podawana jest tylko liczba osób zameldowanych na pobyt stały, natomiast Urząd ds. Cudzoziemców informuje o liczbie cudzoziemców posiadających ważne dokumenty uprawniające do pobytu w Polsce wydane przez wojewodów. Dane te dają zupełnie inny obraz skali imigracji na dany teren.

Biorąc pod uwagę dane dotyczące liczby zameldowanych można wywnioskować, że napływ imigrantów do województwa zachodniopomorskiego nie był duży. W województwie tym zameldowanie na pobyt stały, w latach 2015-2017, wahało się między 649 a 779 osób na rok². Stanowiło ono w skali kraju od 4,8 do 5,8\%. Decyzje o zameldowaniu na pobyt stały w tym województwie podejmowali najczęściej Niemcy i Brytyjczycy. Saldo migracji zagranicznej na pobyt stały w zachodniopomorskim było ujemne. W 2015 roku wyniosło ono minus 1 452, a w 2017 roku minus $191^{3}$. W okresie od 2015 do 2017 roku ponad 55\% cudzoziemców zameldowanych było w mieście Szczecin i podregionie szczecińskim (obejmującym powiaty: goleniowski, gryficki, gryfiński, kamieński, policki, stargardzki) ${ }^{4}$.

\footnotetext{
2 Dane z: Rocznik statystyczny województwa zachodniopomorskiego (2018), Szczecin, s. 112.

${ }^{3}$ Województwo zachodniopomorskie w liczbach (2018), Szczecin, s. 4.

${ }^{4}$ Obliczenia własne na podstawie danych z: Województwo zachodniopomorskie. Podregiony, po-
} 


\section{SM̂PP}

Stan liczebny zameldowanych cudzoziemców w województwie zachodniopomorskim nie pokrywał się z liczbą pozytywnych decyzji, uprawniających do pobytu, wydanych przez wojewodę zachodniopomorskiego. Liczba ta wahała się od 3212 w 2015 roku do 5877 dwa lata później5. W skali kraju było to od 4 do 5\%. Najwięcej decyzji dotyczyło zgody na pobyt czasowy (89-92\%), później pobyt stały i rezydenta długoterminowego UE. W większości przypadków pozytywne decyzje były udziałem mężczyzn (63-66\%). Cudzoziemcy pochodzili najczęściej z państw, których obywatele mieli uproszczoną procedurę otrzymywania zezwoleń na pracę w formie oświadczeń. Byli to przede wszystkim: Ukraińcy (75-86\% w latach 2015-2017), Białorusini, Mołdawianie i Rosjanie ${ }^{6}$.

W 2017 roku ważne dokumenty, uprawniające do pobytu na terenie województwa zachodniopomorskiego, posiadało 19471 cudzoziemców (w skali kraju 305129 osób). Był to wzrost o ponad 3 tysiące w stosunku do roku poprzedniego

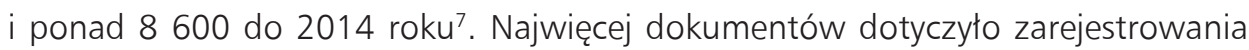
pobytu obywatela UE (8 827, co stanowiło 45\% wszystkich typów dokumentów) oraz pobytu czasowego $(7789-40 \%)^{8}$. W 2017 roku ważne dokumenty, uprawniające do pobytu, wydane przez wojewodę zachodniopomorskiego były w posiadaniu 7898 obywateli Ukrainy (40,6\%), 6904 obywateli Niemiec (35\%), 444 obywateli Włoch i 415 Białorusi?

Napływ cudzoziemców do Polski stał się faktem. Analizując dane statystyczne można stwierdzić, że ich liczba stale rośnie. Nie idzie to jednak w parze z odpowiednim przygotowaniem na ich przyjazd, pobyt i integrację. Do tej pory nie dysponujemy dokumentem określającym doktrynę i założenia polityki migracyjnej. Ponadto obowiązujące programy strategiczne na poziomie kraju nie odnoszą się do kwestii migracji. Dotyczy to także programów ponadregionalnych i wojewódzkich. Zagadnienia migracji nie można jednak pomijać, chociażby z powodu zachodzących zmian demograficznych, które wynikają ze starzenia się społeczeństwa, spadku liczby ludności w wieku produkcyjnym, emigracji, wydłużeniu długości życia czy nadal niskiej dzietności.

W ponadregionalnej strategii, obejmującej między innymi województwo zachodniopomorskie, zauważalne jest jedynie zjawisko emigracji zarobkowej do Niemiec. Mimo że jest ono niepokojące dla autorów dokumentu, to jednak nie wskazuje się

(2017), Szczecin, s. 107; Województwo zachodniopomorskie. Podregiony, powiaty, gminy (2016), Szczecin, s. 107.

${ }^{5}$ Dane pochodzą ze strony https://migracje.gov.pl/statystyki (dostęp: 18.01.2018).

6 Ibidem.

7 Obliczenia własne na podstawie danych ze strony https://migracje.gov.pl/statystyki/zakres/polska/ typ/dokumenty/widok/mapa/rok/2017/?x=0.631\&y=1.6145\&level=1.39533 (dostęp: 18.01.2018).

8 Dane pochodzą ze strony: https://migracje.gov.pl/statystyki/zakres/polska/typ/dokumenty/widok/ mapa/rok/2017/?x=0.631\&y=1.6145\&level=1.39533 (dostęp: 18.01.2018).

9 Dane pochodzą ze strony: https://migracje.gov.pl/statystyki/zakres/polska/typ/dokumenty/widok/ mapa/rok/2017/?x=0.631\&y=1.6145\&level=1.39533 (dostęp: 18.01.2018). 
na możliwość uzupełnienia tej luki na przykład przez cudzoziemców ${ }^{10}$. W przeciwieństwie do tego dokumentu, w strategii województwa zachodniopomorskiego do 2020 roku przewiduje się napływ imigrantów ze Wschodu i Południa. Ma on mieć charakter ekonomiczny ${ }^{11}$. W związku z tym założono, że samorząd będzie wspierał procesy imigracyjne i osiedleńcze poprzez zbudowanie wizerunku tego obszaru jako najlepszego do życia, pracy i wypoczynku². Autorzy dokumentu wskazali na potrzebę prowadzenia , aktywnej polityki imigracyjnej zorientowaną na zaspokojenie potrzeb rynku pracy i utrzymanie potencjału ludnościowego województwa"13. Nie odnieśli się jednak do pojęcia , aktywnej polityki imigracyjnej” i nie wskazali żadnych instrumentów, które miałyby doprowadzić do osiągnięcia wskazanych celów.

W strategii województwa słusznie założono, że imigracja na ten teren będzie miała charakter ekonomiczny. Jak wynika z analiz statystycznych, w latach 2015-2017 na tym obszarze nastąpił ponad dziesięciokrotny wzrost wydanych zezwoleń na pracę dla cudzoziemców i prawie czterokrotny wzrost złożonych przez pracodawców oświadczeń o zamiarze powierzenia im pracy. Zjawisko to nie jest obojętne dla regionalnego rynku pracy. Pojawienie się ich wymaga zatem odpowiedniego przygotowania władz samorządowych. W tym celu niezbędna jest wiedza na temat danych dotyczących skali zjawiska, cech demograficzno-społecznych i ekonomicznych cudzoziemców na danym obszarze. Rozmieszczenie imigrantów ekonomicznych podlega bowiem zróżnicowaniu przestrzennemu i nie dotyczy kraju w tym samym stopniu.

\section{Stan badań}

Badania nad zjawiskiem migracji w nowym kontekście społeczno-politycznym rozpoczęły się wraz z procesem transformacji w 1989 roku. Równocześnie z nasileniem się zjawiska imigracji po 2013 roku, wzrosła liczba badań i ekspertyz poświęconych temu zagadnieniu. Stało się ono przedmiotem zainteresowań wielu dyscyplin nauki, w tym między innymi politologii, demografii, socjologii, ekonomii czy prawa ${ }^{14}$. W ramach

10 Strategia Rozwoju Polski Zachodniej 2020 (2014), przyjęta przez Radę Ministrów w dniu 30 kwietnia 2014 r., https://www.mpit.gov.pl/media/3359/Strategia_Rozwoju_Polski_Zachodniej_do_roku_2020. pdf (dostęp: 5.01.2018).

11 Strategia Rozwoju Województwa Zachodniopomorskiego do roku 2020 (2010), Szczecin czerwiec 2010, s. 21, http://bip.wzp.pl/sites/bip.wzp.pl/files/articles/25816_Strategia\%20Rozwoju\%20Wojew\%27odztwa\%20Zachodniopomorskiego--1.pdf (dostęp: 5.01.2018).

12 Ibidem, s. 27.

13 Ibidem, s. 35.

14 W Raporcie o stanie badań nad migracjami w Polsce po 1989 roku, którego opracowania podjął się Komitet Badań nad Migracjami PAN, red. A Horolets, M. Lesińska, M. Okólski, dokonano przeglądu badań nad migracjami w polskich naukach humanistycznych i społecznych z lat 1989-2018. W opracowaniu uwzględniono siedem obszarów badań migracyjnych (dyscyplin i subdyscyplin), tj. demografię, ekonomię, socjologię, politologię, historię i badania polonijne, antropologię społeczno-kulturową oraz geografię społeczno-ekonomiczną i studia regionalne. Raport o stanie badań nad migracjami w Polsce po 
migracji wiele miejsca poświęcono imigracji zarobkowej, na temat której pojawiły się opracowania m.in. analizujące specyfikę i zmiany na rynku pracy, wskazujące na potrzeby pracodawców czy dotyczące społecznego i politycznego wymiaru imigracji zarobkowej ${ }^{15}$. Inne poświęcone zostały zmianom prawodawstwa w tej dziedzinie ${ }^{16}$.

W krajobrazie badań nad imigracją zarobkową publikowane były także prace wykorzystujące odmienne metodologie, przyjmujące jako przedmiot badań różne aspekty zjawiska migracji, w tym m.in. stopień integracji, gotowość instytucji samorządowych do rozwiązywania problemów i postawy społeczności przyjmującej. O ile uwarunkowania, dynamika i percepcja współczesnej imigracji ekonomicznej do Polski jest tematem często podejmowanym przez badaczy, to województwo zachodniopomorskie pozostawało obszarem niezbadanym w tym zakresie. Wspomniana luka poznawcza dotyczy zwłaszcza badań, które oddawałyby perspektywę i doświadczenie imigrantów tj. badania jakościowe. Niniejszy artykuł jest próbą wyjścia naprzeciw zidentyfikowanym brakom. Powstał on w oparciu o badania zlecone przez Wojewódzką Radę Dialogu Społecznego Wydziału Współpracy Społecznej Urzędu Marszałkowskiego Województwa Zachodniopomorskiego w 2018 roku7.

\section{Metodologia badania}

Ze względu na specyfikę zjawiska, zespół badaczy ${ }^{18}$ skupił się na: 1) wskaźnikach imigracji zarobkowej w województwie zachodniopomorskim (analiza danych urzędowych Departamentu Rynku Pracy Ministerstwa Rodziny, Pracy i Polityki Społecznej oraz Wojewódzkiego Urzędu Pracy w Szczecinie); 2) ocenie sytuacji imigrantów

1989 roku (2018), pod red. A. Horolest, M. Lesińska, M. Okólski, Warszawa, http://www.kbnm. pan.pl/images/Raport_o_stanie_bada\%C5\%84_nad_migracjami_w_Polsce_po_1989_roku.pdf(dostęp: 10.01.2019).

${ }^{15}$ M. Żadkowska, Obywatele Ukrainy na pomorskim rynku pracy. Zarzucone kotwice? O modelach migracji Ukraińców i Ukrainek na Pomorzu (2017), Gdańsk; Obywatele Ukrainy pracujący w Polsce - raport z badania (2017), I. Chmielewska, G. Dobroczek, A. Panuciak, Warszawa; Migranci na polskim rynku pracy. Rzeczywistość, problemy, wyzwania (2007), pod red. W. Klausa, Warszawa; Popyt na pracę cudzoziemców. Polska i sąsiedzi (2004), pod red. S. Golinowskiej, Warszawa; M. Duszczyk, Polska polityka imigracyjna a rynek pracy (2012), Warszawa; S. Kubiciel-Lodzińska, Zatrudnienie cudzoziemców w przedsiębiorstwach. Determinanty i perspektywy (przykład województwa opolskiego), (2016), Katowice; K. Andrejuk, Przedsiębiorcy ukraińscy w Polsce. Struktura i sprawstwo w procesie osiedlenia (2016), Warszawa.

${ }^{16}$ Zatrudnianie cudzoziemców (2015), E. Bielak-Jomaa (red.), Warszawa; E. Podgórska-Rakiel, M. Szypniewski, Zatrudnienie w Polsce cudzoziemców spoza UE (2018), Warszawa; M. Makowski, Zatrudnianie cudzoziemców po zmianach w 2018 r. Nowe zasady zatrudniania i dodatkowe obowiązki (2018), Warszawa; L.A. Rubińska, Praca cudzoziemców z Ukrainy i innych państw wschodnich. Zatrudnianie, opodatkowanie i ubezpieczenia społeczne (2018), Gdańsk; P. Ciszek (red.), M. Nocuń, G. Ziomkowski, Zatrudnianie cudzoziemców w Polsce - m.in. z Armenii, Białorusi, Gruzji, Mołdawii, Rosji, Ukrainy, państw UE (2018), Gdańsk.

${ }^{17}$ Badanie zrealizowane na zlecenie Wojewódzkiej Rady Dialogu Społecznego Wydział Współpracy Społecznej UM WZP w listopadzie oraz grudniu 2018 roku.

${ }^{18}$ Zespół badawczy: dr hab. Maciej Kowalewski, prof. US (Uniwersytet Szczeciński), dr hab. Anita Adamczyk, prof. UAM (Uniwersytet im. Adama Mickiewicza), dr Robert Bartłomiejski (Uniwersytet Szczeciński), dr Dorota Kowalewska (Uniwersytet Szczeciński), dr Regina Thurow, Klaudia Szałach, Daria Ubych. 
zarobkowych na zachodniopomorskim rynku pracy na podstawie opinii cudzoziemców oraz ekspertów (wywiady indywidualne i grupowe).

Badania i analizę danych realizowano w listopadzie i grudniu 2018 roku. Na etapie prac analitycznych dysponowano cząstkowymi statystykami publicznymi za I półrocze 2018 roku. Indywidualne i grupowe wywiady pogłębione realizowano na terenie dwóch miast: Szczecina i Goleniowa. Wybór ten był podyktowany analizą danych z raportu Wojewódzkiego Urzędu Pracy w Szczecinie Powierzenie wykonywania pracy cudzoziemcom na podstawie oświadczenia pracodawcy w województwie zachodniopomorskim w 2017 roku19. Na jego podstawie można wywnioskować, że w 2017 roku w Szczecinie i powiecie goleniowskim wydano najwięcej oświadczeń o powierzeniu pracy cudzoziemcom (w kolejności 27710 i 8 069²0). Wśród podejmujących pracę najwięcej było Ukraińców, tj. 8634 osób (88,35\%).

W powiatowych urzędach pracy na obszarze województwa zachodniopomorskiego pracodawcy lub podmioty zamierzające powierzyć wykonywanie krótkoterminowej pracy cudzoziemcowi złożyli łącznie 70478 oświadczeń. 94,4\% z nich dotyczyło pracowników z Ukrainy²1. Według raportu Wojewódzkiego Urzędu Pracy w Szczecinie (WUP) najwięcej oświadczeń o zatrudnieniu cudzoziemca składały szczecińskie agencje zatrudnienia i poszukiwania pracowników. Według Polskiej Klasyfikacji Działalności (PKD) prowadziły one aktywność w sekcji N czyli „działalność w zakresie usług administrowania i działalność wspierająca". To skutkowało największą liczbą wydanych oświadczeń (20 404), z których 75\% przypadło na Szczecin (15 151). Z kolei powiat goleniowski wyróżniał się największym udziałem w województwie oświadczeń w sekcji A „rolnictwo, leśnictwo, łowiectwo i rybactwo” (1 839 oświadczeń pracodawców) ${ }^{22}$.

Dotarcie do imigrantów w obu miejscowościach było możliwe dzięki zastosowaniu techniki „kuli śniegowej”. W efekcie, zrealizowano większą liczbę wywiadów niż pierwotnie zakładano. Na etapie planowania zakresu badania za konieczne uznano przeprowadzenie 30 wywiadów IDI (indywidualne wywiady pogłębione), a ostatecznie przeprowadzono ich 45 (25 z mężczyznami i 20 z kobietami). Respondenci, którzy uczestniczyli w badaniu byli w wieku 18-59 lat. Średnia wieku wyniosła 34 lata. Wśród respondentów znaleźli się głównie Ukraińcy, a poza nimi także obywatele Armenii, Rosji i Białorusi. Pierwsi z nich w najmniejszym stopniu doświadczali trudności związanych z barierą językową. Dominujące w społeczeństwie przekonanie, że pracownikami imigrującymi do Polski są „tylko Ukraińcy” przedłożyło się na sposób

19 Powierzenie wykonywania pracy cudzoziemcom na podstawie oświadczenia pracodawcy w województwie zachodniopomorskim w 2017 roku, (2017), WUP, Szczecin, https://www.wup.pl/images/uploads/ II_DLA_INSTYTUCI/statystyka_analizy_badania/analizy_i_opracowania/2017/Powierzenie_wykonywania pracy_cudzoziemcom_na_podstawie_o\%C5\%9Bwiadczenia_pracodawcy_w_wojew\%C3\%B3dztwie_zachodniopomorskim_w_2017 roku.pdf (dostęp: 20.11.2018).

20 Ibidem, s. 10.

21 Ibidem.

22 Ibidem, s. 12. 


\section{SM̂PP}

postrzegania pozostałych grup narodowościowych i do pewnego stopnia prowadziło do „unieważniania” różnic pomiędzy obywatelami takich krajów jak Armenia, Białoruś czy Rosja.

Poza wywiadami indywidualnymi przeprowadzono także grupowe. Miały one na celu dostarczenie rozpoznań odnoszących się do grupowych poglądów ekspertów zajmujących się rynkiem pracy i jego otoczeniem na temat zjawiska imigracji zarobkowej w województwie zachodniopomorskim. Udział ekspertów związanych z pośrednictwem pracy i zarządzaniem zatrudnieniem był ważnym wyznacznikiem zarówno pozytywnych, jak i negatywnych doświadczeń obecności cudzoziemców na rynku pracy. Wstępne założenia próby obejmowały uczestnictwo 5 osób. Ostatecznie po wstępnym etapie badań i konsultacjach z ekspertami do udziału w panelu ekspertów zaproszono 13 osób. Z kolei w panelu imigrantów wzięło udział 14 osób.

\section{Skala imigracji zarobkowej w województwie zachodniopomorskim}

Zdiagnozowanie sytuacji cudzoziemców w województwie zachodniopomorskim należy rozpocząć od krótkiego scharakteryzowania regionalnego rynku pracy, ponieważ dostępność pracy wydaje się głównym czynnikiem motywującym do przyjazdu. Stopa bezrobocia rejestrowanego w województwie zachodniopomorskim na koniec 2018 roku była najniższa od momentu jego powołania, czyli od 1999 roku. Liczba bezrobotnych w województwie zachodniopomorskim wynosiła, w grudniu 2018 roku, 46002 osób, a stopa bezrobocia 7,4\%23. W dwóch okresach referencyjnych od listopada (odpowiednio 2016 i 2017 roku) do października (2017 i 2018 roku) liczba wolnych miejsc pracy i miejsc aktywizacji zawodowej zgłaszanych przez pracodawców w omawianym województwie utrzymywała się średnio na podobnym poziomie (tj. $E(X)=6832,75$ w I okresie; $E(X)=6$ 678,83 w II okresie). Na koniec listopada 2018 roku na jedną ofertę pracy przypadało 10 bezrobotnych, wobec 16 w roku poprzednim ${ }^{24}$. Powyższa analiza zachodniopomorskiego rynku pracy wskazuje na poprawiającą się sytuację gospodarczą.

Jak wynika z danych za I półrocze 2018 roku zawody deficytowe w regionie to: magazynierzy i pokrewni, kierowcy operatorzy wózków jezdniowych, kontrolerzy procesów przemysłowych, operatorzy urządzeń do produkcji wyrobów szklanych i ceramicznych, operatorzy urządzeń do spalania odpadów i uzdatniania wody, sprzątacze, pracownicy przygotowujący posiłki typu fast-food, pracownicy wykonujący dorywcze prace proste, robotnicy robót stanu surowego, robotnicy do zwalczania

23 Podstawowe dane o bezrobociu, https://www.wup.pl/pl/dla-instytucji/statystyka-badania-i-analiza/ podstawowe-dane-o-bezrobociu/ (dostęp:10.01.2019).

24 Informacja o rynku pracy w województwie zachodniopomorskim w listopadzie 2018 roku, https:// www.wup.pl/pl/dla-instytucji/statystyka-badania-i-analiza/dane-statystyczne/ (dostęp: 10.01.2019). 
szkodników i chwastów, asystenci nauczycieli, analitycy systemów komputerowych, przedstawiciele handlowi, kierownicy ds. finansowych ${ }^{25}$. Z kolei do tzw. zawodów nadwyżkowych, wymagających dobrego wykształcenia i biegłej znajomości języka polskiego, zaliczały się: dealerzy i maklerzy aktywów finansowych, kierownicy ds. strategii i planowania, pracownicy ds. statystyki, finansów i ubezpieczeń, pracownicy przy pracach przygotowawczych do druku, technicy analityki medycznej, mistrzowie produkcji w budownictwie, monterzy sprzętu elektrycznego, operatorzy maszyn i urządzeń dźwigowo-transportowych ${ }^{26}$.

Na podstawie powyższych danych można zauważyć zjawisko dualizmu rynku pracy ${ }^{27}$, tj. podział na rynek lepszy (bardziej atrakcyjny, wymagający wyższych kwalifikacji) i gorszy (nieatrakcyjny, charakteryzujący się powtarzalnością wykonywanej pracy, najczęściej fizycznej, niewymagającej wysokich kwalifikacji) ${ }^{28}$. Powyższą tezę potwierdzają analizy WUP w Szczecinie, odnoszące się do danych z powiatowych urzędów pracy za 2017 rok, które monitorowały przebieg rejestracji oświadczeń pracodawców o zamiarze powierzenia wykonywania pracy cudzoziemcom. Wynika z nich, że pracodawcy poszukiwali głównie pracowników przy pracach prostych (45\%), robotników przemysłowych i rzemieślników (28,4\%), pracowników usług i sprzedawców $(11,7 \%)$, operatorów i monterów maszyn i urządzeń (7,3\%), rolników, ogrodników, leśników i rybaków (3,7\%), pracowników biurowych $(2,0 \%)$, techników i inny średni personel $(1,7 \%)$, specjalistów $(0,3 \%)^{29}$. W regionie można zatem zaobserwować nadpodaż wysoko wykwalifikowanych specjalistów oraz deficyt w zawodach niewymagających specjalnych umiejętności i wiedzy. Powyższą lukę pracodawcy starają się wypełnić zatrudniając cudzoziemców.

W 2017 roku w powiatowych urzędach pracy, na obszarze województwa zachodniopomorskiego, pracodawcy złożyli łącznie 70478 oświadczeń o zamiarze powierzenia wykonywania pracy cudzoziemcom, tj. 14874 więcej niż rok wcześniej

${ }_{25}$ Monitoring zawodów deficytowych i nadwyżkowych w I półroczu 2018 roku - Informacja sygnalna (2018), WUP Szczecin, s. 6, https://www.wup.pl/images/uploads/II_DLA_INSTYTUCJI/statystyka_analizy_badania/statystyki_rynku_pracy/monitoring/Monitoring_zawod\%C3\%B3w_deficytowych_i_nadwy\%C5\%BCkowych_w_I_p\%C3\%B3\%C5\%82roczu_2018_roku__Informacja_sygnalna.pdf (dostęp: 11.01.2018).

26 Ibidem, s. 7.

27 Por: Kacperska M. (2018), Imigranci zarobkowi na polskim rynku pracy, „Środkowoeuropejskie Studia Polityczne" nr 2; Kacperska M. (2017), Is the European Union's Border a Labor Market's Border as Well? Third Country Migrants in the Polish Labor Market, w: Immigration Crises, Borders and the European Union, red. J. Jańczak, Berlin; D. Kałuża - Kopias (2016), Imigranci na polskim rynku pracy według statystyk MPiPS, „Studia Ekonomiczne” nr 258; E. Kryńska, E. Kwiatkowski, Podstawy wiedzy o rynku pracy (2013), Łódź; E. Kryńska, Segmentacja rynku pracy - podstawy teoretyczne i analiza statystyczna (1966), Łódź; W. Kozek (2013), Rynek pracy. Perspektywa instytucjonalna, Warszawa; A. Mrozowicki, M. Maciejewska (2016), Segmentacja rynku pracy, prekaryjne zatrudnienie a strategie związków zawodowych na poziomie branżowym: przypadek Polski, „Prakseologia” nr 158.

28 Doeringer P.B., Piore M.J. Unemployment and the dual labour market, w: "The Public Interest" (1975) 38, s. 67-79; Musiał-Paczkowska A., Segmentacja rynku pracy (2003), w: Kopycińska D. (red.) Kapitał ludzki w gospodarce, Szczecin, s. 75.

29 Powierzenie wykonywania pracy..., op. cit., s. 6. 


\section{SM̂PP}

i 52150 niż dwa lata wstecz ${ }^{30}$. Wzrosła również liczba wydawanych zezwoleń na pracę dla cudzoziemców w Polsce. W 2017 roku w województwie zachodniopomorskim wydano ich 9772 (w skali kraju 235 626), tj. o 5562 więcej niż rok wcześniej i o 8750 więcej niż w 2015 roku $^{31}$. Oznacza to, że w latach 2015-2017 w województwie zachodniopomorskim nastąpił ponad dziewięciokrotny wzrost wydanych zezwoleń na pracę dla cudzoziemców i prawie czterokrotny wzrost złożonych przez pracodawców oświadczeń o zamiarze powierzenia im pracy. W świetle danych przedstawionych w tabeli $\mathrm{nr} 1$, liczba zezwoleń na pracę dla cudzoziemców w Polsce, jak i województwie zachodniopomorskim systematycznie rosła. W 2014 roku liczba przyznawanych zezwoleń w regionie wyniosła 809. W kolejnych latach wskaźnik ten stale wzrastał, osiągając poziom 9772 zgód na pracę w 2017 roku. Od 2013 roku do końca pierwszej połowy 2018 roku wydano łącznie 23713 zezwoleń na pracę, z czego większość, bo 19890 (tj. 84,37\%), przyznano Ukraińcom. Poza nimi do województwa zachodniopomorskiego w celach zarobkowych przybyli obywatele: Białorusi (622 zezwolenia, tj. 2,64\%), Mołdawii (362, tj. 1,54\%), Nepalu (338, tj. 1,43\%), Filipin (316, tj. 1,34\%), Bangladeszu (273, 1,16\%), Indii (198, tj. 0,84\%), Gruzji (106 z, tj. 0,45\%) i Rosji (105, tj. 0,45\%). W latach 2013-2017 na stałym, relatywnie niskim poziomie utrzymywało się wydawanie zezwoleń na pracę obywatelom: Uzbekistanu (191, tj. 0,81\%), Turcji (130, tj. 0,55\%), Chin (118, tj. 0,50\%), Tajlandii $\left(121\right.$, tj. 0,51\%) oraz Wietnamu $\left(87\right.$, tj. 0,37\%) ${ }^{32}$.

W porównaniu do zezwoleń na pracę dla cudzoziemców, popularniejszą formą pozyskiwania pracowników w regionie przez pracodawców była uproszczona procedura oświadczeniowa. Od 2014 roku notowany był wyraźny wzrost liczby rejestrowanych oświadczeń o zamiarze powierzenia pracy obywatelom państw trzecich. W ciągu pięciu ostatnich lat pracodawcy z województwa najczęściej wykazywali zamiar powierzenia pracy obywatelom Ukrainy (146 318 deklaracji, tj. 95,38\% w latach 2013-2017). W tym okresie odnotowano także wzrost liczby deklaracji o zamiarze zatrudnienia obywateli Białorusi, Mołdawii i Gruzji, a w mniejszym stopniu Ormianom i Rosjanom (zob. tabela nr 1). Zjawisko corocznego zwiększania się liczby wydawanych zezwoleń było charakterystyczne dla wszystkich 16 województw, jednak skala i tempo zmian były nierównomiernie rozłożone.

Łączna liczba oświadczeń zarejestrowanych przez powiatowe urzędy pracy w Polsce w 2017 roku wyniosła 1824 464, z czego 755900 dotyczyło osób, które już posiadały wizę lub zezwolenie na pracę. Cudzoziemcy, podejmujący pracę w Polsce na podstawie oświadczeń, byli najczęściej płci męskiej (65,04\%). Kobiety stanowiły ok. 34,96\% wśród ubiegających się o możliwość pracy w Polsce w ramach

\footnotetext{
30 Powierzenie wykonywania pracy..., op. cit., s. 9.

${ }^{31}$ Zobacz w tabeli 1, opracowanie własne na podstawie danych Departamentu Rynku Pracy MRPiPS za lata 2013-2018 (I połowa).

32 Ibidem.
} 
oświadczenia33. Procentowy udział kobiet w danej grupie narodowej był najniższy w przypadku obywatelek Białorusi (15,64\%), a najwyższy - obywatelek Ukrainy (35,9\%). Wśród cudzoziemców z sześciu państw trzecich, objętych tzw. preferencyjną procedurą oświadczeń, w 2017 roku 43,98\% stanowiły osoby w wieku 26-40 lat. Oznacza to, że na emigrację zarobkową do Polski decydowali się ludzie stosunkowo młodzi, którzy byli na etapie zakładania rodzin i w wieku produkcyjnym. Najwięcej osób w kategorii wiekowej 26-40 lat było wśród obywateli Mołdawii (54,97\%), a najmniej wśród obywateli Ukrainy (43,61\%). Tylko nieliczne grono cudzoziemców powyżej 65. roku życia decydowało się na pracę w Polsce $(0,13 \%)$. Nie istniały zatem istotne odstępstwa od struktury społeczno-demograficznej w przypadku oświadczeń, jak i zezwoleń na pracę ${ }^{34}$.

Należy podkreślić, że liczba cudzoziemców, która podjęła pracę w związku z zarejestrowanym oświadczeniem, nie musiała być tożsama z liczbą zarejestrowanych oświadczeń. Oznacza to, że nie można było bezpośrednio zsumować liczebności wydanych zezwoleń i zarejestrowanych oświadczeń. Wynika to m.in. z faktu, że dla części cudzoziemców zarejestrowano więcej niż jedno oświadczenie. Dane rejestrowane były w powiatowych urzędach pracy na podstawie pisemnych oświadczeń podmiotów gospodarczych, chcących powierzyć wykonywanie pracy cudzoziemcowi, a więc przed faktycznym podjęciem pracy. W praktyce osoba ubiegająca się o zatrudnienie, mogła figurować na więcej niż jednym oświadczeniu. Ponadto zdarzały się przypadki, w których pracodawca odstępował od zatrudnienia cudzoziemca. Miało to miejsce na przykład w sytuacjach nieuznania deklarowanych wcześniej na dyplomie umiejętności, odmowy wydania wizy przez konsula czy niestawienia się cudzoziemca w miejscu pracy. Mimo to, deklaracje wpisane do ewidencji powiatowych urzędów pracy w poszczególnych województwach, można traktować jako wskaźnik trendu imigracji zarobkowej. Województwo zachodniopomorskie w skali kraju nie cieszyło się dużym zainteresowaniem cudzoziemców korzystających z tzw. uproszczonej procedury zatrudnienia. Warto jednak podkreślić, że w latach 2013-2017 liczba deklaracji pracodawców w województwie zachodniopomorskim wzrosła ponad dwudziestokrotnie z poziomu 3250 (tj. 1,38\% z ogółu 2013 roku) oświadczeń wpisanych do ewidencji przez powiatowe urzędy pracy do poziomu 70478 (tj. 3,86\% z ogółu 2017 roku) 35.

Najwyższą frekwencję rejestracji oświadczeń w 2017 roku odnotowano w Szczecinie tj. 27 710, stanowiących 39,3\% wszystkich w regionie. Pozostałe powiaty w regionie zachodniopomorskim charakteryzowały się znacznie mniejszą liczbą rejestracji. W powiecie goleniowskim do rejestru wpisano - 8069 oświadczeń (tj. 11,4\%), mieście Koszalin - 5667 (8,0\%), kołobrzeskim - 5002 (7,1\%), polickim - 3030 (4,3\%),

33 Rejestracja oświadczeń pracodawców o zamiarze powierzenia pracy cudzoziemcowi, Departament Rynku Pracy MRPiPS, http://psz.praca.gov.pl/web/urzad-pracy/-/8180205-rejestracja-oswiadczen-pracoda wcow-o-zamiarze-powierzenia-pracy-cudzoziemcowi (dostęp: 2.01.2019).

34 Ibidem.

35 Powierzenie wykonywania pracy..., op. cit., s. 9. 


\section{SM̂PP}

sławieńskim - 2757 (3,9\%). Na średnim poziomie rejestracji w skali województwa znalazły się powiaty: gryfiński - 2462 (3,5\%), kamieński - 2306 (3,3\%), myśliborski - 1928 (2,7\%), miasto Świnoujście - 1924 (2,7\%), koszaliński - $1770(2,5 \%)$, białogardzki - 1720 (2,4\%), stargardzki - 1680 (2,4\%), gryfiński - 1152 (1,6\%), świdwiński - 1071 (1,5\%). W dolnym kwartylu znalazły się powiaty: choszczeński $719(1,0 \%)$, pyrzycki $-400(0,6 \%)$, wałecki - $336(0,5 \%)$, szczecinecki - $324(0,5 \%)$, tobeski - $263(0,4 \%)$, drawski - $188(0,3 \%)^{36}$.

Poza wyżej omówionymi możliwościami podjęcia pracy w Polsce przez cudzoziemców w 2018 roku, ustawodawca wprowadził nową procedurę, a mianowicie zezwolenie na pracę sezonową. Daje ona możliwość obywatelom państw trzecich zatrudnienia przez okres nie dłuższy niż 9 miesięcy w roku kalendarzowym, w zakresie działalności bezpośrednio związanej z rolnictwem, leśnictwem, łowiectwem, rybołówstwem, zakwaterowaniem i usługami gastronomicznymi ${ }^{37}$. Ze względu na fakt, że o zezwolenie na pracę sezonową pracodawca może się starać dla cudzoziemca przebywającego już legalnie w Polsce, jak i dla cudzoziemca, który dopiero będzie się ubiegał o wjazd w celu podjęcia pracy, dysponujemy trzema statystykami obrazującymi skalę korzystania z tej procedury. I tak z danych wynika, że w województwie zachodniopomorskim, w pierwszym półroczu 2018 roku, złożono 5048 wniosków, co stanowiło 3,19\% w skali kraju. Z kolei liczba zezwoleń na pracę sezonową wydanych przez Powiatowe Urzędy Pracy w tym samym okresie, równa była 2110 (tj. 3,4\% w skali kraju), a liczba zaświadczeń wpisanych do ewidencji wniosków w sprawie pracy sezonowej wyniosła $109304^{38}$.

Liczba wniosków o zezwolenie na pracę sezonową według obywatelstwa dostępna jest na razie na poziomie ogólnopolskim. $Z$ analizy danych statystycznych wynika, że największe zainteresowanie pracą sezonową wykazywali obywatele Ukrainy (154 315 wniosków). Poza nimi grono to uzupełniali obywatele: Nepalu (1 165 wniosków), Białorusi (1 008), Mołdawii (467), Bangladeszu (438), Indii (345) i Gruzji $(240)^{39}$. W przeciwieństwie do pozostałych procedur (oświadczeń i zezwolenia na pracę), zezwolenie na pracę sezonową cieszyło się popularnością wśród kobiet. Do nich trafiło 63,15\% (tj. 39220 zezwoleń) wszystkich zezwoleń na pracę sezonową wydawanych przez Powiatowe Urzędy Pracy, od stycznia do czerwca 2018 roku ${ }^{40}$. Większość pracowników sezonowych z krajów trzecich była w wieku 25-34 lata (29,28\%, tj. 18182 osób) i 35-44 lata (28\%, tj. 17391 osób). Z kolei młodzież do

36 Ibidem

37 Rozporządzenie Ministra Rodziny, Pracy i Polityki Społecznej z dnia 8 grudnia 2017 r. w sprawie podklas działalności według Polskiej Klasyfikacji Działalności (PKD), w których wydawane są zezwolenia na pracę sezonową cudzoziemca, Dz. U. 2017, poz. 2348.

38 Zezwolenia na pracę sezonową cudzoziemca, Departament Rynku Pracy MRPiPS (2018), http:// psz.praca.gov.pl/web/urzad-pracy/-/8180228-zezwolenia-na-prace-sezonowa-cudzoziemca (dostęp: 26.11.2018).

39 Ibidem.

40 Ibidem. 
Tabela 1

Wydane zezwolenia na pracę dla cudzoziemców według obywatelstwa w województwie zachodniopomorskim (w liczbach bezwzględnych, w latach 2013-2017 z danymi za I półrocze 2018)

\begin{tabular}{|c|c|c|c|c|c|c|}
\hline \multirow{3}{*}{ Obywatelstwo } & \multicolumn{6}{|c|}{ Rok } \\
\hline & \multicolumn{2}{|c|}{2013} & \multicolumn{2}{|c|}{2014} & \multicolumn{2}{|c|}{2015} \\
\hline & $\mathrm{N}$ & $\%$ & $\mathrm{n}$ & $\%$ & $n$ & $\%$ \\
\hline POLSKA & 39078 & & 43663 & & 65786 & \\
\hline ZACHODNIOPOMORSKIE & 895 & $100,00 \%$ & 670 & $100,00 \%$ & 1022 & $100,00 \%$ \\
\hline Ukraina & 500 & $55,87 \%$ & 403 & $60,15 \%$ & 837 & $81,90 \%$ \\
\hline Białoruś & 24 & $2,68 \%$ & 10 & $1,49 \%$ & 12 & $1,17 \%$ \\
\hline Mołdawia & 10 & $1,12 \%$ & 8 & $1,19 \%$ & 3 & $0,29 \%$ \\
\hline Nepal & 5 & $0,56 \%$ & 8 & $1,19 \%$ & 3 & $0,29 \%$ \\
\hline Filipiny & 9 & $1,01 \%$ & 1 & $0,15 \%$ & 5 & $0,49 \%$ \\
\hline Bangladesz & 3 & $0,34 \%$ & 1 & $0,15 \%$ & 14 & $1,37 \%$ \\
\hline Indie & 12 & $1,34 \%$ & 6 & $0,90 \%$ & 4 & $0,39 \%$ \\
\hline Uzbekistan & 15 & $1,68 \%$ & 39 & $5,82 \%$ & 4 & $0,39 \%$ \\
\hline Turcja & 25 & $2,79 \%$ & 21 & $3,13 \%$ & 12 & $1,17 \%$ \\
\hline Tajlandia & 37 & $4,13 \%$ & 24 & $3,58 \%$ & 9 & $0,88 \%$ \\
\hline Korea Północna & 32 & $3,58 \%$ & 24 & $3,58 \%$ & 42 & $4,11 \%$ \\
\hline Chiny & 61 & $6,82 \%$ & 1 & $0,15 \%$ & 8 & $0,78 \%$ \\
\hline Gruzja & 3 & $0,34 \%$ & 2 & $0,30 \%$ & 4 & $0,39 \%$ \\
\hline Rosja & 6 & $0,67 \%$ & 6 & $0,90 \%$ & 8 & $0,78 \%$ \\
\hline Wietnam & 20 & $2,23 \%$ & 19 & $2,84 \%$ & 14 & $1,37 \%$ \\
\hline Armenia & 15 & $1,68 \%$ & 9 & $1,34 \%$ & 2 & $0,20 \%$ \\
\hline Pakistan & 8 & $0,89 \%$ & 1 & $0,15 \%$ & 3 & $0,29 \%$ \\
\hline Inne & 110 & $12,29 \%$ & 87 & $12,99 \%$ & 38 & $3,72 \%$ \\
\hline
\end{tabular}

Źródło: opracowanie własne na podstawie danych Departamentu Rynku Pracy MRPiPS za lata 2013-2018 (I połowa).

24 lat stanowiła 18\% (11 178 osób), a prawie co piąty cudzoziemiec wykonujący pracę sezonową był w wieku 45-54 lata (11 593 osób, tj. 18,67\%). Najmniej zezwoleń wydano cudzoziemcom powyżej 55. roku życia $(6,05 \%)$ oraz powyżej 64 . roku życia $(0,27 \%)^{41}$. W świetle danych urzędowych zaobserwowano wzrost atrakcyjności 
Tabela $1 \mathrm{~cd}$.

\begin{tabular}{|c|c|c|c|c|c|c|c|}
\hline \multicolumn{2}{|c|}{2016} & \multicolumn{2}{|c|}{2017} & \multicolumn{2}{|c|}{ I pół. 2018} & \multicolumn{2}{|c|}{ Razem: } \\
\hline $\mathrm{N}$ & $\%$ & $n$ & $\%$ & $\mathrm{n}$ & $\%$ & $\mathrm{~N}$ & $\%$ \\
\hline 127394 & & 235626 & & 147981 & & 659528 & \\
\hline 4210 & $100,00 \%$ & 9772 & $100,00 \%$ & 7005 & $100,0 \%$ & 23574 & $100,00 \%$ \\
\hline 3796 & $90,17 \%$ & 8634 & $88,35 \%$ & 5720 & $81,7 \%$ & 19890 & $84,37 \%$ \\
\hline 76 & $1,81 \%$ & 241 & $2,47 \%$ & 259 & $3,7 \%$ & 622 & $2,64 \%$ \\
\hline 42 & $1,00 \%$ & 163 & $1,67 \%$ & 136 & $1,9 \%$ & 362 & $1,54 \%$ \\
\hline 8 & $0,19 \%$ & 117 & $1,20 \%$ & 197 & $2,8 \%$ & 338 & $1,43 \%$ \\
\hline 17 & $0,40 \%$ & 69 & $0,71 \%$ & 215 & $3,1 \%$ & 316 & $1,34 \%$ \\
\hline 24 & $0,57 \%$ & 68 & $0,70 \%$ & 163 & $2,3 \%$ & 273 & $1,16 \%$ \\
\hline 16 & $0,38 \%$ & 105 & $1,07 \%$ & 55 & $0,8 \%$ & 198 & $0,84 \%$ \\
\hline 21 & $0,50 \%$ & 69 & $0,71 \%$ & 43 & $0,6 \%$ & 191 & $0,81 \%$ \\
\hline 27 & $0,64 \%$ & 29 & $0,30 \%$ & 16 & $0,2 \%$ & 130 & $0,55 \%$ \\
\hline 19 & $0,45 \%$ & 19 & $0,19 \%$ & 13 & $0,2 \%$ & 121 & $0,51 \%$ \\
\hline 20 & $0,48 \%$ & 1 & $0,01 \%$ & 0 & $0,0 \%$ & 119 & $0,50 \%$ \\
\hline 16 & $0,38 \%$ & 18 & $0,18 \%$ & 14 & $0,2 \%$ & 118 & $0,50 \%$ \\
\hline 4 & $0,10 \%$ & 32 & $0,33 \%$ & 61 & $0,9 \%$ & 106 & $0,45 \%$ \\
\hline 16 & $0,38 \%$ & 42 & $0,43 \%$ & 27 & $0,4 \%$ & 105 & $0,45 \%$ \\
\hline 4 & $0,10 \%$ & 11 & $0,11 \%$ & 19 & $0,3 \%$ & 87 & $0,37 \%$ \\
\hline 2 & $0,05 \%$ & 16 & $0,16 \%$ & 0 & $0,0 \%$ & 44 & $0,19 \%$ \\
\hline 1 & $0,02 \%$ & 21 & $0,21 \%$ & 0 & $0,0 \%$ & 34 & $0,14 \%$ \\
\hline 101 & $2,40 \%$ & 117 & $1,20 \%$ & 67 & $1,0 \%$ & 520 & $2,21 \%$ \\
\hline
\end{tabular}

Polski jako celu imigracji zarobkowej. Dane dotyczące dynamiki wzrostu liczby imigrantów zarobkowych w podziale na województwa (zob. tabela nr 2) sugerują, że zachodniopomorskie nie było ich pierwszym wyborem. Moment zwrotny nastąpił dopiero w 2016 roku.

Na zakończenie tej części, należy zauważyć, że skala imigracji zarobkowej wyrażona w statystykach publicznych nie odzwierciedlała rzeczywistego stanu faktycznego 
$\frac{1}{n}$
$\frac{0}{0}$
$\frac{0}{2}$

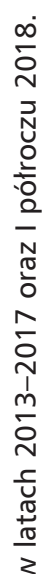

$\frac{\varepsilon}{\sqrt{n}}$

글

$\sum^{3}$ 음

$\frac{0}{0}$

.

$\frac{\mathrm{N}}{\mathrm{C}}$

Ч্ত

는

웡

할

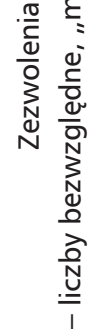

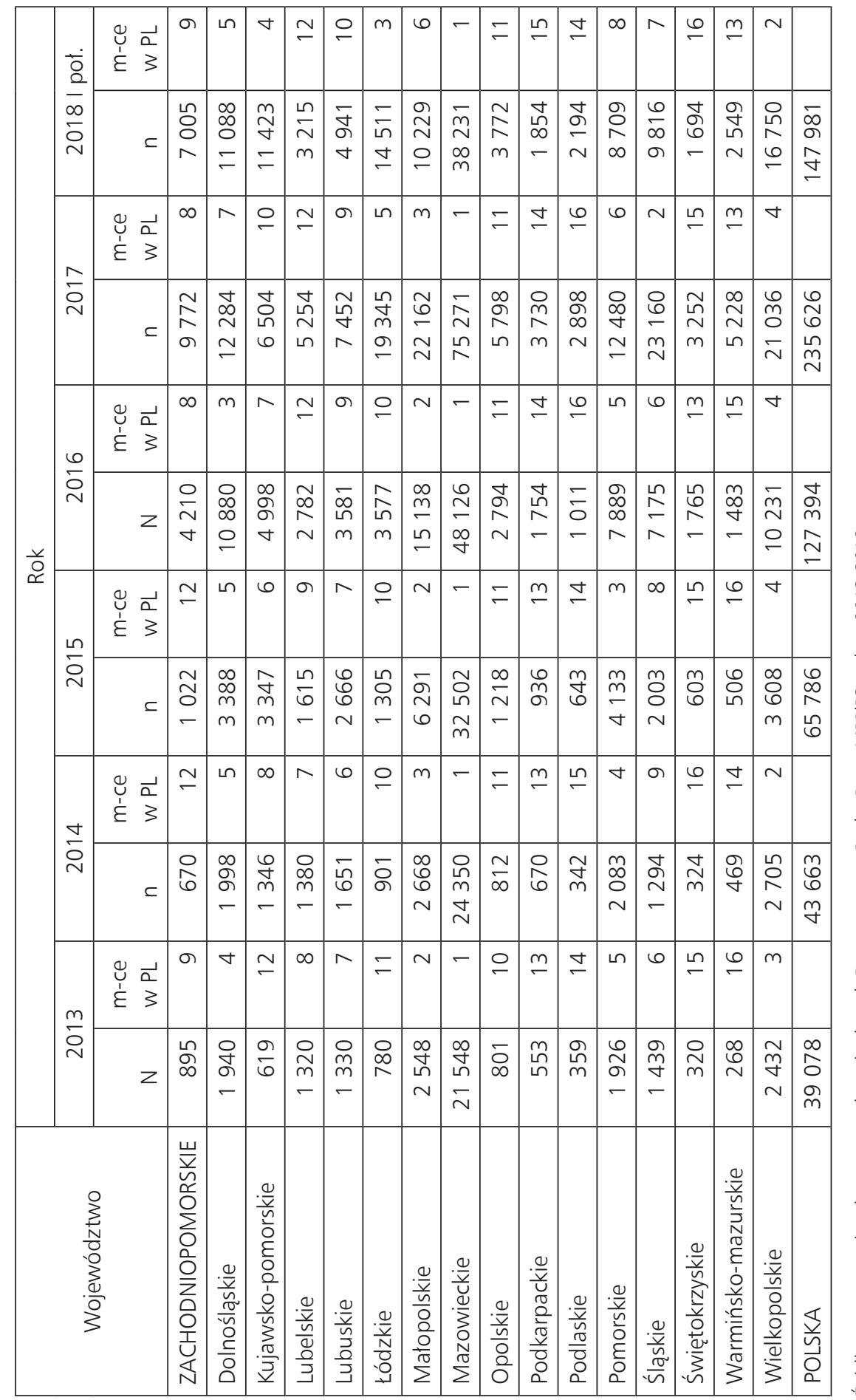




\section{SM̂PP}

zjawiska. Nadmieniano już, że prezentowana liczba cudzoziemców, która podjęła pracę w związku z zarejestrowanym oświadczeniem, nie była tożsama z liczbą zarejestrowanych oświadczeń. Niniejsza analiza nie uwzględnia również tych cudzoziemców, którzy zdecydowali się na nielegalne wykonywanie pracy na terenie województwa.

\section{Warunki życia i pracy w opinii imigrantów zarobkowych}

Z treści przeprowadzonych wywiadów z imigrantami zarobkowymi można wywnioskować, że Polska jest państwem, w którym „wszystko jest dla ludzi”, a warunki życia w regionie oceniane były pozytywnie. Szczecin opisywany był natomiast jako miasto "dobre do życia". Nie oznacza to oczywiście, że imigranci nie dostrzegli wad pobytu w Polsce. Praktycznie we wszystkich wywiadach pojawiał się problem z kartą pobytu i uciążliwościami związanymi z procedurą jej uzyskiwania. Respondenci, którym kończyła się ważność sześciomiesięcznego oświadczenia pracodawcy o zamiarze zatrudnienia, wskazywali na znacznie wydłużony czas oczekiwania na legalizację pobytu. Badani obawiali się, że nie uzyskają na czas dokumentu zezwalającego na dalszy pobyt i pracę w Polsce, a tym samym podczas kontroli narażeni będą na deportację.

Cudzoziemcy po przyjeździe do Polski doświadczali różnych sytuacji związanych z funkcjonowaniem na rynku pracy, a zebrane dane pozwoliły na uchwycenie tych odmiennych przypadków. Większość z nich podejmowała szereg aktywności zmierzających do poprawy swojej sytuacji na rynku pracy, nie zważając na negatywne doświadczenia. W świetle zgromadzonych danych imigranci zarobkowi stanowili przykład grupy "doskonale mobilnej"42 na rynku pracy, a więc wkładającej wysiłek w znalezienie satysfakcjonującej ich pracy.

Złe doświadczenia (w miejscu pracy, jak i codziennym życiu) były wynikiem zróżnicowanych czynników. Wśród nich były m.in.: naruszanie prawa pracy przez polskich pracodawców, brak znajomości instytucji publicznych, przepisów prawnych, brak odpowiednich kompetencji językowych i nieznajomość realiów polskiego rynku pracy. Respondenci rzadko deklarowali posiadanie satysfakcjonującej pracy (ze względu na warunki zatrudnienia albo wysokość płacy) niezależnie od wieku, wykształcenia i płci. Powyższe stwierdzenia znalazły odzwierciedlenie w przytaczanych wypowiedziach respondentów.

Przed przyjazdem poznałem urzędnika w pociągu, który powiedział, że ma fermę ze świniami, a ja potrzebowałem pieniędzy, spotkałem się z tym facetem, ale coś tam było

${ }^{42}$ W modelu idealnym rynku pracy opisywanym m.in. przez Wiesławę Kozek (2013) mowa jest o sile roboczej doskonale mobilnej, tj. o pracownikach konkurujących ze sobą i gotowych do konsekwentnego poszukiwania lepiej płatnej pracy. Pisząc o imigrantach jako grupie „doskonale mobilnej” mamy na myśli takie cechy jak: brak przywiązania do jednego pracodawcy, gotowość do zmiany pracy i umiejętność dostosowania się do pojawiających się ofert pracy, nawet poniżej posiadanych własnych kwalifikacji zawodowych. 
nie tak, tam były straszne warunki, były tylko 3 godziny snu, zadzwoniłem do Pana Jana i przyjechatem do Szczecina, poszedłem tu do pracy, jestem już tu prawie 3 lata i jestem bardzo zadowolony. Odkąd przyjechałem, to nie myślatem wtedy, że będę w Polsce. Przyjechałem tu tylko na urlop, ale po 2 miesiącach zobaczyłem, że zarobiłem dobre pieniądze (wywiad 5, M, 26 lat).

To moja czwarta praca. Jak ja przyjechałem, to nie chciałem oficjalnie pracować, teraz to jest inna sytuacja, wcześniej to nie chciałem oficjalnie, bo większe podatki... (później). Myślę, że Polak to zatrudni oficjalnie, pojechałem nad morze do sklepu sprzedawać warzywa. Pracowatem od 7 do 23.30 bez odpoczynku, 7 dni w tygodniu. Ja jestem uczciwy, a nie mogłem nawet z nikim pogadać przez chwilę, bo pracodawca nie pozwalał. Popracowałem u niego miesiąc i poszedłem do jego sąsiada do restauracji, tam było jedzenie, mniej pracy, śniadanie, obiad i kolacja. Facet obiecywat, że zatrudni oficjalnie i kiedy ja złożyłem w urzędzie o kartę pobytu i mówię, że potrzebuję umowę to ciągle przekładat, aż powiedziat, że umowy nie da, bo na jesień zamyka biznes (wywiad 7, M, 59 lat).

Motywacje cudzoziemców przyjeżdżających do województwa zachodniopomorskiego w celu podjęcia pracy były zróżnicowane. Wśród czynników wypychających były na przykład: konflikt wojenny, nacjonalizacja własności prywatnej, utrata mieszkań, pracy, lęk o własne zdrowie i najbliższych (jak ma to miejsce w przypadku mieszkańców południowo-wschodniej Ukrainy). Dla młodych mężczyzn wyjazd do Polski był ucieczką od wcielenia do armii, a innym Ukraińcom dawał szansę życia w pokoju z dala od działań wojennych (Jestem z Ługańska to jest $w$ tej chwili miasto okupowane przez Rosję i przez to 4 lata temu, kiedy zaczęła się wojna musiałam wyjechać (wywiad 6, K, 29 lat); Wszystko zależy od sytuacji na Ukrainie, bo tam jest stan wojenny (wywiad 8, M, 25 lat). Kolejnym powodem wyjazdu, na który wskazywali respondenci, była zła sytuacja ekonomiczna oraz polityczna w państwie pochodzenia.

Respondenci, którzy mają dzieci, motywowali swój przyjazd potrzebą zapewnienia bezpieczeństwa, stabilnych warunków ekonomicznych dla utrzymania rodziny oraz lepszej przyszłości dla rozwoju potomstwa. Wśród czynników przyciągających osoby pomiędzy 18 a 30 rokiem życia do przyjazdu do województwa zachodniopomorskiego wymieniano także: oddalenie od Ukrainy, transgraniczne położenie województwa, a także postmigracyjny charakter regionu. Wśród respondentów dominował profil imigracji łańcuchowej: przyjazdy do współmałżonka, osób z dalszej rodziny czy przyjaciół.

Do Szczecina przyjechałam, bo mam tutaj rodzinę i oni wszystko załatwili, żebym miała pracę. Teraz jestem tutaj, żeby zarabiać więcej niż na Ukrainie (wywiad 4, K, 23 lata).

Dlatego postanowiliśmy przyjechać tu do Szczecina, bo koledzy stąd byli gotowi nas przyjąć do domu i zdecydowaliśmy, że pojedziemy tu, bo nam pomogą i będzie prościej, bo pomogą z mieszkaniem i tak dalej. Ale z tego, co wiem to na zachodzie Polski, pensje są niższe niż w innych częściach kraju (wywiad 6, M, 22 lata). 


\section{SM̂PP}

Mój brat pracował na ogrodach i my tam z żoną pojechaliśmy spróbować na 3 tygodnie i wróciliśmy na Ukrainę, później jako kierowca, później trochę w Elblągu pracowałem, na początku było dobrze, ale później przyjechało dużo Ukraińców, żona dostała ciężką pracę przy deskach i zrezygnowaliśmy (...) Szwagier był tu w Szczecinie, robit przy remontach, potrzebował ludzi to my z żona tutaj pojechaliśmy. Pracuję w Szczecinie od 5 miesięcy (wywiad 11, M, 39 lat).

W poszukiwaniu pracy - zdaniem respondentów - najbardziej skuteczne było korzystanie z sieci kontaktów indywidualnych. W praktyce oznaczało to, że informację o możliwości podjęcia pracy uzyskiwano od rodziny czy znajomych, którzy wcześniej byli zatrudnieni w Polsce. W ocenie badanych, polski rynek pracy stwarzał duży wachlarz możliwości zatrudnienia, a przyjazd do Polski bez gwarancji pracy nie stanowił wielkiego ryzyka (Wszędzie potrzebują, sam wybierałem sobie dziedzinę, w której chciałbym pracować. (wywiad 3, M, 49 lat)). Część badanych korzystała z usług biur pośrednictwa pracy. Ocena funkcjonowania tych instytucji była zróżnicowana. W wielu opiniach pojawiały się informacje o nieuczciwych praktykach biur, nierzetelności przekazywanych informacji dotyczących charakteru pracy i wysokości płacy (Biura naciągają finansowo. (panel z imigrantami, M, 22 lata); Agencja miała załatwić wizę na wyjazd, pracy szukałam sama. 80\% to oszuści przynajmniej na Ukrainie, oni chcą tylko zarobić pieniądze, drugi człowiek ich nie interesuje. (wywiad 17, K, 38 lat)). Zwracano również uwagę na wysokie koszty świadczonych usług z zakresu pośrednictwa pracy.

Na ogół imigranci nie podejmowali pracy zgodnie ze swoimi kwalifikacjami. Większość z nich nie poszukiwała pracy w swoim zawodzie ze względu na przekonanie, że podstawową barierą zatrudnienia zgodnego z kwalifikacjami jest nieznajomość języka polskiego i problemy z uznawalnością kwalifikacji (oraz wykształcenia) zdobytych w państwie pochodzenia.

Stosunkowo rzadko ${ }^{43}$ zawierano z cudzoziemcami umowę o pracę, nie dotyczyło to jednak osób przebywających przez dłuższy okres w Polsce lub posiadających wysokie kwalifikacje. Zdaniem respondentów, pozostawanie w tzw. szarej strefie związane było m.in. z pracą podejmowaną na krótki okres i dodatkowymi kosztami, które musiał ponieść pracodawca w związku z dodatkowymi kosztami pracy. Respondenci zwracali uwagę, że w wykonywaniu każdej pracy liczyło się zaangażowanie, jakość wykonywanej pracy, a w mniejszym stopniu posiadane kwalifikacje. Zdaniem badanych, pracodawcy dostrzegali zaangażowanie cudzoziemców i wysoko oceniali efektywność pracy.

Na regionalnym rynku pracy istniało zapotrzebowanie na pracowników posiadających wysokie kwalifikacje. Brak pracowników o określonych kompetencjach zmuszał

${ }^{43}$ Ze względu na jakościowy a nie ilościowy charakter badania trudno jest określić precyzyjnie skalę zjawiska. W próbie badawczej brak umowy o pracę (w odniesieniu do całej historii zatrudnienia w Polsce) wskazało 37 respondentów (w łącznej liczbie 45 badanych). 
pracodawców do organizowania wszelkiego rodzaju szkoleń, celem których było zdobycie nowej wiedzy i podniesienie kwalifikacji zawodowych. W szkoleniach tych uczestniczyli również cudzoziemcy, co wiązało się z dodatkowym pozytywnym efektem, czyli wydłużeniem okresu zatrudnienia u jednego pracodawcy.

W zakresie wynagradzania cudzoziemców za wykonywaną pracę można było spotkać się z różnymi praktykami stosowanymi przez pracodawców. Wśród badanych panowało przeświadczenie, że za pracę, która wymagała podobnych kompetencji, cudzoziemcy otrzymywali niższe wynagrodzenie niż Polacy. Ilustracją tego rodzaju poglądów są między innymi następujące wypowiedzi: Jak przyjdzie Ukrainiec do pracy to wszystko jest dobrze, pieniądze nie są takie same co Polak zarabia, jest różnica 5 zł na godzinę. Polak zarabia więcej. Ja mam umowę zlecenie, a Polak ma umowę o pracę (wywiad 11, M, 39 lat); Mam wykształcenie w budowlance inżynierskie. Pracuję ciężko na budowie i zawsze mówią, że Ukraince można zapłacić mniej (panel z imigrantami, K, 52 lata). Niższe wynagrodzenie cudzoziemców usprawiedliwiano często ponoszeniem kosztów ich zakwaterowania przez pracodawców. Istotnym problemem wskazywanym przez badanych były nadużycia dokonywane przez agencje zatrudnienia (ze wskazaniem na podmioty ukraińskie), które wiązały się z ustalaniem niskich stawek płac lub pobieraniem nieuzasadnionych prowizji od wynagrodzenia. Respondenci wskazywali przykłady naruszeń przepisów BHP, a także złych warunków socjalnych. Pracodawcy z tego tytułu nie ponosili konsekwencji, a cudzoziemcom nie udzielano właściwej pomocy. Mimo przykładów naruszeń praw pracowniczych, respondenci wyrażali także pozytywne opinie na temat warunków płacowych, socjalnych, w zakresie przestrzegania przepisów BHP czy traktowania pracowników przez pracodawców.

Imigranci znaczną część własnej aktywności i czasu przeznaczali na pracę lub jej poszukiwanie. Cudzoziemcy, zwłaszcza ci, którzy przyjechali na krótki okres do pracy w Polsce, decydowali się na wydłużenie godzin pracy, chcąc w ten sposób pozyskać jak największe środki finansowe. Zdarzały się również przypadki wymuszania wydłużonego czasu pracy przez pracodawców. Problem ten odzwierciedlają poniższe przykłady:

Jak on pracuje od poniedziałku do soboty po kilkanaście godzin dziennie, a czasami w niedziele również, to on nie ma ochoty o godzinie 21 wychodzić z domu i gdzieś się tam z kimś spotykać.

Oni są ogromnie zapracowani, nawet poświęcić jajko na święto wielkanocne przyszli pod wieczór, bo wcześniej byli w pracy.

Pracodawca powinien rozumieć i mieć jakieś granice, ile jego pracownik pracuje, raz na jakiś czas można popracować więcej, ale nie przez cały czas (panel ekspercki).

W świetle zebranych wywiadów, relacje imigrantów z pracodawcami były różnorodne. Z jednej strony, niektórzy respondenci spotykali się z równym traktowaniem w miejscu pracy, życzliwością i pomocą w rozwiązywaniu problemów nie tylko 


\section{SM̂PP}

zawodowych, ale również życiowych. Z drugiej strony, przytaczane były przykłady dyskryminowania, braku akceptacji i nierównego traktowania cudzoziemców w miejscu pracy. Sytuacje takie dotyczyły zarówno relacji pracodawca - pracownik, jak i relacji między samymi pracownikami. Niektóre przypadki dyskryminacji w miejscu pracy związane były z mobbingiem, zastraszaniem, brakiem możliwości upominania się o swoje prawa - co było efektem zależności ekonomicznej od pracodawcy.

Imigranci wskazywali także na własne - niskie - zaufanie do państwowych instytucji. Wynikało to zarówno z ich negatywnych doświadczeń w kraju pochodzenia, jak i w Polsce. Wśród respondentów powszechna była opinia na temat uciążliwości związanych z uzyskaniem tzw. karty pobytu. Wynikały one zarówno ze słabej znajomości obowiązującego prawa i procedur przez imigrantów, jak i ograniczonych możliwości obsłużenia wszystkich osób składających wnioski w Zachodniopomorskim Urzędzie Wojewódzkim. W efekcie tworzyły się długie kolejki, które trudno było zmniejszyć, nawet przy istniejącym systemie rejestracji (osobiste stawienie się w urzędzie, rejestracja elektroniczna, przesłanie dokumentów pocztą tradycyjną). Respondenci wskazywali, że mieli problemy z dotrzymaniem terminów uzyskania w określonym czasie kart pobytu, co w konsekwencji prowadziło do deportacji.

Jednym z kluczowych pytań, dotyczących imigrantów zarobkowych w województwie zachodniopomorskim (jako regionie przygranicznym), była kwestia ewentualnej dalszej migracji do Niemiec. Niezależnie od otwarcia rynku niemieckiego na imigrantów, plany zawodowe respondentów były zróżnicowane. Znaczna część osób (w opiniach respondentów dotyczyło to połowy pracujących imigrantów) chciała pozostać w regionie. Zdaniem badanych wpływ na to mogłaby mieć realizacja przyjaznej cudzoziemcom polityki. W jej ramach mógłby znaleźć się program legalizacji pobytu dla osób pracujących nielegalnie. Zwracano uwagę, że takie rozwiązania były i są stosowane w innych państwach. Część respondentów brała pod uwagę możliwość wyjazdu do pracy, do Niemiec. Ewentualność taka byłaby możliwa, mimo dostrzegania barier kulturowych i językowych. W takich przypadkach najistotniejszymi argumentami były względy finansowe.

Z badań wynika, że zróżnicowanie jakości życia imigrantów w województwie zachodniopomorskim zależało od rodzaju wykonywanej pracy, posiadanych kwalifikacji, długości pobytu w Polsce i sytuacji rodzinnej. Warunki mieszkaniowe badanych miały związek z długością planowanego okresu pobytu w regionie. Osoby przyjeżdżające na krótki czas poszukiwały jak najtańszego zakwaterowania, godząc się często na wyjątkowo niski standard mieszkania (Jeżeli człowiek przyjechał zarobić, to jest zmuszony wynająć tanio i skromnie, bo nie będzie wydawał pół pensji na mieszkanie, a jak ktoś przyjeżdża na stałe, to starają się zjednoczyć ze znajomymi i razem wynająć sobie całe mieszkanie (wywiad 23, M, 34 lata); Mieszkają w takich warunkach, że normalni ludzie mieszkają we dwójkę, a Ukraińcy mieszkają po 10 osób. Zużycie mediów, mieszkania, wiadomo, jak mieszka w jednym czasie tyle ludzi to wszystko się szybciej niszczy (panel ekspercki)). Problemem podnoszonym przez respondentów była niechęć Polaków 
do wynajmowania mieszkań imigrantom zarobkowym, a także ich zameldowania. Jest bardzo duży problem, żeby mieszkania wynajmować cudzoziemcom, nie tylko Ukraińcom, ale innym obcokrajowcom (panel z imigrantami, K, 52 lata); ja też staram się im pomagać, niektórych Ukraińców zameldowałam u siebie w mieszkaniu, żeby mogli dostać kartę (panel ekspercki). Bariera ta była konsekwencją funkcjonowania stereotypów w postrzeganiu osób przyjeżdżających zza granicy wschodniej.

Nieco inaczej wyglądał problem mieszkaniowy imigrantów, którzy podjęli decyzję o pozostaniu w województwie zachodniopomorskim na stałe. Ta grupa respondentów na ogół sprowadzała swoje rodziny i wynajmowała mieszkanie. Z upływem czasu podejmowali decyzję o jego zakupie. Realizacja tego zamiaru - jak wskazywali badani - była jednak trudna z dwóch powodów. Po pierwsze, banki niechętnie udzielały kredytów cudzoziemcom, a po drugie - wymagana była zgoda Ministerstwa Obrony z uwagi na przygraniczne położenie regionu.

W zakresie dostępu do edukacji, a także traktowania dzieci imigrantów przez nauczycieli i rówieśników, nie wyrażano negatywnych opinii. Dużo znajomych pyta, jak w szkole dziecko sobie radzi, bo chcą przyjechać i się martwi. To im mówię, żeby się martwili o siebie, bo dzieci to problemów nie mają z językiem jak są małe. (wywiad 19, K, 29 lat); Do czwartej u nas wszystkie dzieci obcokrajowców mają język polski i nie są to tylko dzieci z Ukrainy, są to na przykład też dzieci z Wietnamu, nie ma różnicy, która to klasa, co roku odbywają się te zajęcia. Oczywiście zajęcia te się odbywają, jeżeli rodzice i dzieci tego chcą. (panel ekspercki). Postulatem respondentów było wprowadzenie na świadectwie szkolnym oceny z języka ukraińskiego. Problem ten zgłaszano w odniesieniu do imigrantów pochodzenia ukraińskiego, którzy stanowili większość osób przybywających do województwa zachodniopomorskiego.

Podczas wywiadów respondenci pytani byli o dostępność do usług instytucji pomocy społecznej. Zgodnie z prawem ze świadczeń mogły korzystać osoby o uregulowanym statusie, które znalazły się w trudnej sytuacji ekonomicznej. W odmiennej sytuacji znajdowały się osoby, które nie miały legalnego pobytu (między innymi ze względu na długotrwałość niektórych procedur) i z tego powodu były pozbawione wsparcia socjalnego.

Z 500+ mieliśmy problem, za pierwszym razem się nie udało, napisali mi list, w którym mój mąż powinien donieść dokumenty, że pracuje, a on nie może, bo straż go zabierze, bo nie ma karty, miał odmowę. W Warszawie zostały wszystkie dokumenty niedokończone. Straż Graniczna powiedziała, że mamy napisać odwołanie i czekać rok. A kto będzie czekać. Ojciec musi wyjechać, dziecko póki co jest małe, ale będę musiała wrócić do pracy, kto będzie się dzieckiem opiekować, a mąż ma wyjechać, to zostanę sama (wywiad 10, K, 33 lata).

Część imigrantów zarobkowych z uwagi na pracę w tzw. szarej strefie nie była ubezpieczona, a pracownicy na ogół nie ubezpieczali się prywatnie. Badani zwracali również uwagę na nieuczciwe praktyki pracodawców, którzy nie odprowadzali 


\section{SM̂PP}

składek na ubezpieczenie zdrowotne (mimo zalegalizowania pracy), w rezultacie czego pracownicy nie mogli korzystać z pomocy medycznej.

Mam kilka znajomych kobiet ciężarnych tutaj w Polsce, co okazało się, że mają problem z zarejestrowaniem się do lekarza, aby w przyszłości mieć opiekę lekarską. Niby była zatrudniona legalnie, a z tego wynika, że jednak nie i za poród będzie musiała zapłacić $z$ własnej kieszeni (panel ekspercki).

W relacjach lekarz-pacjent przeważały przykłady dobrych praktyk. Lekarze wykazywali duże zrozumienie i udzielali pomocy także w sytuacjach problemów komunikowania się w języku polskim. Tak, lekarz zawsze wszystko wytłumaczy co i jak, bez problemu (wywiad 24, K, 26 lat). W ocenie dostępu do usług medycznych krytyczne uwagi dotyczyły ograniczonej pomocy specjalistycznej oraz długich kolejek oczekiwania na wizytę u lekarza.

Teraz, jak jestem w ciąży, to trochę łatwiej, bo nie muszę stać w kolejkach, ale wcześniej to było ciężko. Doktorzy okej, ale kolejki makabryczne (wywiad 10, K, 33 lata).

A jak ocenia Pan dostęp do służby zdrowia?

Byle jaki.

Czyli na Białorusi jest lepiej w tej kwestii?

O wiele lepiej. Tutaj na przykład zapisując się do okulisty wizyta jest dopiero za 4 miesiące, na Białorusi na następny dzień (wywiad 1, M, 23 lata).

\section{Zakończenie}

Dynamicznie rosnący trend podejmowania pracy zarobkowej przez cudzoziemców w Polsce, zbiega się w czasie z systematycznym spadkiem poziomu bezrobocia (w kraju i regionie). W Polsce ma miejsce znaczny niedobór pracowników, zwłaszcza w zakresie tzw. prac prostych. Ponadto nie wykorzystuje się optymalnie krajowego kapitału ludzkiego, jak i tego z zagranicy. W drugim przypadku dotyczy to przede wszystkim Ukraińców pracujących często na stanowiskach poniżej swoich kwalifikacji. Na obecnym etapie dane wykluczają ewentualne argumentacje, aby imigracja zarobkowa do Polski skutkowała wzrostem konkurencji na rynku pracy między Polakami a cudzoziemcami.

Większość imigrantów zarobkowych w województwie zachodniopomorskim stanowili Ukraińcy. Ich przyjazd do Szczecina i regionu zachodniopomorskiego podyktowany był w pierwszej kolejności relatywnie wysokimi zarobkami, a następnie bliskością językową oraz kulturową. Analiza zachodniopomorskiego rynku pracy wykazała jego podział na specjalistyczny ( „atrakcyjny") i prosty ( „nieatrakcyjny"). Rynek ten charakteryzował się nadwyżką osób wysoko wykształconych w młodym wieku, których kwalifikacje zawodowe nie były wykorzystywane. W zestawieniu z konkurencyjnością 
niemieckiego rynku pracy, ta sytuacja może mieć dotkliwe konsekwencje dla lokalnego rynku pracy: w województwach graniczących z Niemcami może nastąpić odpływ tzw. cudzoziemców sezonowych i planujących pobyt czasowy, dla których argument finansowy jest dominujący. W przypadku imigrantów planujących pozostanie na stałe w Polsce, bliskość językowa i kulturowa będzie być może działała na korzyść krajowego rynku pracy, ale już niekoniecznie województwa zachodniopomorskiego. Jego przygraniczna lokalizacja może skutkować tym, że cudzoziemcy będą mieszkać w województwie, ale pracować w Niemczech.

\section{Bibliografia}

Andrejuk K. (2016), Przedsiębiorcy ukraińscy w Polsce. Struktura i sprawstwo w procesie osiedlenia, Warszawa, Wydawnictwo IFIS PAN.

Barometr imigracji zarobkowej. I półrocze 2018. Ukraiński pracownik w Polsce (2018), Warszawa, Personel Service.

Ciszek P. (red.), M. Nocuń, G. Ziomkowski (2018), Zatrudnianie cudzoziemców w Polsce m.in. z Armenii, Białorusi, Gruzji, Mołdawii, Rosji, Ukrainy, państw UE, Gdańsk, Wydawnictwo dla Biznesu ODDK.

Duszczyk M. (2012), Polska polityka imigracyjna a rynek pracy, Warszawa, Aspra.

Doeringer P.B., Piore M.J. (1971), Internal labour markets and manpower analysis, Lexington, Heath.

Doeringer P.B., Piore M.J. (1975), Unemployment and the dual labour market, „, The Public Interest", 38, pp. 67-79.

Informacja o rynku pracy w województwie zachodniopomorskim w listopadzie 2018 roku, Opracowanie własne WUP w Szczecinie na podstawie sprawozdania o rynku pracy MRPiPS-01, załącznika nr 1 do sprawozdania MRPiPS-01 i danych GUS, https://www.wup.pl/pl/dla-instytucji/statystyka-badania-i-analiza/dane-statystyczne/

Kacperska M. (2018), Imigranci zarobkowi na polskim rynku pracy, „Środkowoeuropejskie Studia Polityczne" nr 2, s. 137-156.

Kacperska M. (2017), Is the European Union's Border a Labor Market's Border as Well? Third Country Migrants in the Polish Labor Market, w: Immigration Crises, Borders and the European Union, red. J. Jańczak, Berlin, Logos Verlag.

Kałuża-Kopias D. (2016), Imigranci na polskim rynku pracy według statystyk MPiPS, "Studia Ekonomiczne" nr 258, Zeszyty Naukowe Uniwersytetu Ekonomicznego w Katowicach" nr 258, s. 17-28.

Kozek W. (2013), Rynek pracy. Perspektywa instytucjonalna, Warszawa, Wydawnictwa Uniwersytetu Warszawskiego.

Kryńska E., Kwiatkowski E. (2013), Podstawy wiedzy o rynku pracy, Łódź, Wydawnictwo Uniwersytetu Łódzkiego.

Kryńska E. (1966), Segmentacja rynku pracy - podstawy teoretyczne i analiza statystyczna, Łódź, Wydawnictwo Uniwersytetu Łódzkiego.

Kubiciel-Lodzińska S. (2016), Zatrudnienie cudzoziemców w przedsiębiorstwach. Determinanty i perspektywy (przykład województwa opolskiego), Katowice, Wydawnictwo Uniwersytetu Ekonomicznego w Katowicach. 


\section{SM̂PP}

Makowski M. (2018), Zatrudnianie cudzoziemców po zmianach w 2018 r. Nowe zasady zatrudniania i dodatkowe obowiązki, Warszawa, INFOR PL.

Migranci na polskim rynku pracy. Rzeczywistość, problemy, wyzwania, (2007), Klaus W. (red.) Warszawa, Stowarzyszenie Interwencji Prawnej.

Monitoring zawodów deficytowych i nadwyżkowych w I półroczu 2018 roku - Informacja sygnalna (2018), WUP Szczecin, https://www.wup.pl/images/uploads/II_DLA_INSTYTUCJI/statystyka_analizy_badania/statystyki_rynku_pracy/monitoring/Monitoring_zawod\%C3\%B3w_deficytowych_i_nadwy\%C5\%BCkowych_w_I_p\%C3\%B3\%C5\%82roczu_2018_roku_-_Informacja_sygnalna.pdf

Mrozowicki A., Maciejewska M. (2016), Segmentacja rynku pracy, prekaryjne zatrudnienie a strategie związków zawodowych na poziomie branżowym: przypadek Polski, „Prakseologia” 158 (1), s. 361-391.

Musiał-Paczkowska A. (2003), Segmentacja rynku pracy, w: Kopycińska D. (red.) Kapitał ludzki w gospodarce, Szczecin, Polskie Towarzystwo Ekonomiczne.

Obywatele Ukrainy pracujący w Polsce - raport z badania (2018), I. Chmielewska, G. Dobroczek, A. Panuciak, Warszawa, Departament Statystyki NBP.

Podgórska-Rakiel E., Szypniewski M. (2018), Zatrudnienie w Polsce cudzoziemców spoza UE, Warszawa, Wolters Kluwer Polska.

Podstawowe dane o bezrobociu, https://www.wup.pl/pl/dla-instytucji/statystyka-badania-i-analiza/ podstawowe-dane-o-bezrobociu/

Popyt na pracę cudzoziemców. Polska i sąsiedzi, Golinowska S. (red.) (2004), Warszawa, Instytut Pracy i Spraw Socjalnych.

Powierzenie wykonywania pracy cudzoziemcom na podstawie oświadczenia pracodawcy w województwie zachodniopomorskim w 2017 roku, (2017), WUP, Szczecin, https://www.wup.pl/ images/uploads/II_DLA_INSTYTUCI/statystyka_analizy_badania/analizy_i_opracowania/2017/ Powierzenie_wykonywania_pracy_cudzoziemcom_na_podstawie_o\%C5\%9Bwiadczenia_pracodawcy_w_wojew\%C3\%B3dztwie_zachodniopomorskim_w_2017_roku.pdf

Raport o stanie badań nad migracjami w Polsce po 1989 roku (2018), A. Horolest, M. Lesińska, M. Okólski (reds), Warszawa, Komitet Badań nad Migracjami Polskiej Akademii Nauk, http://www.kbnm.pan.pl/images/Raport_o_stanie_bada\%C5\%84_nad_migracjami_w_Polsce_po_1989_roku.pdf

Rejestracja oświadczeń pracodawców o zamiarze powierzenia pracy cudzoziemcowi, Departament Rynku Pracy MRPiPS, http://psz.praca.gov.pl/web/urzad-pracy/-/8180205-rejestracja-oswiadc zen-pracodawcow-o-zamiarze-powierzenia-pracy-cudzoziemcowi

Rocznik statystyczny województwa zachodniopomorskiego (2018), Szczecin, Urząd Statystyczny w Szczecinie.

Rozporządzenie Ministra Rodziny, Pracy i Polityki Społecznej z dnia 8 grudnia 2017 r. w sprawie podklas działalności według Polskiej Klasyfikacji Działalności (PKD), w których wydawane są zezwolenia na pracę sezonową cudzoziemca, Dz. U. 2017, poz. 2348.

Rubińska L.A. (2018), Praca cudzoziemców z Ukrainy i innych państw wschodnich. Zatrudnianie, opodatkowanie i ubezpieczenia społeczne, Gdańsk, Wydawnictwo dla Biznesu ODDK.

Strategia Rozwoju Polski Zachodniej 2020 (2014), przyjęta przez Radę Ministrów w dniu 30 kwietnia 2014 r., https://www.mpit.gov.pl/media/3359/Strategia_Rozwoju_Polski_Zachodniej_do_ roku_2020.pdf 
Strategia Rozwoju Województwa Zachodniopomorskiego do roku 2020 (2010), Szczecin czerwiec 2010, s. 21, http://bip.wzp.pl/sites/bip.wzp.pl/files/articles/25816_Strategia\%20Rozwoju\%20 Wojew\%27odztwa\%20Zachodniopomorskiego--1.pdf

Ustawa z dnia 20 kwietnia 2004 roku o promocji zatrudnienia i instytucjach rynku pracy, Dz. U. 2018, poz. 1265.

Województwo zachodniopomorskie. Podregiony, powiaty, gminy (2017), Szczecin, Urząd Statystyczny w Szczecinie.

Województwo zachodniopomorskie. Podregiony, powiaty, gminy (2016), Szczecin, Urząd Statystyczny w Szczecinie.

Województwo zachodniopomorskie. Podregiony, powiaty, gminy (2018), Szczecin, Urząd Statystyczny w Szczecinie.

Województwo zachodniopomorskie w liczbach (2018), Szczecin, Szczecin, Statystyczny w Szczecinie.

Zatrudnianie cudzoziemców (2015), E. Bielak-Jomaa (red.), Warszawa, Wolters Kluwer Polska.

Zezwolenia na pracę sezonową cudzoziemca, Departament Rynku Pracy MRPiPS (2018), http:// psz.praca.gov.pl/web/urzad-pracy/-/8180228-zezwolenia-na-prace-sezonowa-cudzoziemca

Żadkowska M. (2017), Obywatele Ukrainy na pomorskim rynku pracy. Zarzucone kotwice? O modelach migracji Ukraińców i Ukrainek na Pomorzu, Gdańsk, Wojewódzki Urząd Pracy w Gdańsku.

https://migracje.gov.pl/statystyki

https://migracje.gov.pl/statystyki/zakres/polska/typ/dokumenty/widok/mapa/rok/2017/?x=0.631\&y$=1.6145$ \&level $=1.39533$ 